\title{
Comprehensive molecular and clinical analysis of adalimumab and etanercept therapeutic potential in patients with psoriatic arthritis
}

\author{
Dominika Wcisło-Dziadecka1 ${ }^{1}$, Beniamin Grabarek ${ }^{2,3}$, Andrzej S. Swinarew ${ }^{4}$, Beata Rozwadowska ${ }^{1}$, Nikola Zmarzły ${ }^{2,5}$, \\ Joanna Gola ${ }^{5}$
}

${ }^{1}$ Department of Cosmetology, Faculty of Pharmaceutical Sciences in Sosnowiec, Medical University of Silesia in Katowice, Poland ${ }^{2}$ Department of Histology, Cytophysiology and Embryology, Faculty of Medicine in Zabrze, University of Technology in Katowice, Poland ${ }^{3}$ Department of Clinical Trials, Maria Sklodowska-Curie National Research Institute of Oncology, Krakow Branch, Krakow, Poland ${ }^{4}$ Institute of Materials Science, Faculty of Computer Science and Material Science, University of Silesia, Katowice, Poland ${ }^{5}$ Department of Molecular Biology, Faculty of Pharmaceutical Sciences in Sosnowiec, Medical University of Silesia in Katowice, Poland

Adv Dermatol Allergol 2020; XXXVII (2): 262-268

DOI: https://doi.org/10.5114/ada.2020.94847

\begin{abstract}
Introduction: Adalimumab and etanercept are drugs used in anti-TNF therapy in patients with psoriasis and psoriatic arthritis. Despite the molecular targeting of these drugs, the loss of pharmacological response to treatment is observed in patients. The development of personalized medicine makes it possible to use not only clinical parameters of disease severity, but also molecular marker systems.

Aim: The aim of the study was to evaluate the changes in TNF- $\alpha$, TNFR1, and TNFR2 expression in relation to parameters of disease severity (PASI, BSA, DAS28) in patients treated with adalimumab and etanercept. We have attempted to determine whether changes in the TNF- $\alpha$, TNFR1, and TNFR2 expression profile may be a useful molecular marker of the therapeutic potential of anti-TNF drugs.

Material and methods: The study group consisted of 3 patients initially treated with adalimumab, followed by etanercept. The control group included 20 healthy volunteers. The expression profile of TNFR1 and TNFR2 was determined at the mRNA level, while TNF- $\alpha$ expression was evaluated at the transcriptome and proteome levels using the RT-qPCR method (transcriptional activity assay) and MALDI-TOF MS (protein level assessment).

Results: Depending on the drug, different expression profiles of the studied cytokines are observed.

Conclusions: The obtained data indicate that TNF- $\alpha$, TNFR1, and TNFR2 may be useful markers of the efficacy of anti-TNF therapy, thus complementing clinical parameters.
\end{abstract}

Key words: anti-TNF therapy, psoriasis, molecular marker, resistance in therapy, personalized medicine.

\section{Introduction}

Psoriasis is a multifactorial, pro-inflammatory disease with a complex immunopathogenesis, affecting $1-3 \%$ of the population, usually between 20-30 and 50-60 years of age [1-3]. A characteristic clinical symptom is parakeratosis [2], while at the molecular level, changes in the concentration profile of cytokines e.g. tumour necrosis factor- $\alpha$ (TNF- $\alpha$ ), interleukins (IL-12, IL-23, IL-17), transforming growth factor $\beta$ (TGF- $\beta$ ) are observed $[1,4]$.

Depending on psoriasis severity, conventional therapy including local and systemic treatment is used, and in the absence of its effects, patients are qualified for anti-cytokine therapy $[4,5]$. This type of therapy includes two important groups of drugs: TNF- $\alpha$ inhibitors (adalimumab, etanercept) and IL-12/23 inhibitor (ustekinumab) $[6,7]$. It is recommended for patients with PASI $>10$ or BSA $>10$ (parameters of disease severity) and meeting also the other requirements set out in the qualification for the drug programme [5, 8]. These drugs are characterized by unique specificity of action as well as quick and long-lasting effect [8-10].

Adalimumab is a fully human monoclonal antibody that has the ability to neutralize both membrane-bound and soluble forms of TNF- $\alpha$, thereby interrupting the sig-

Address for correspondence: Assoc. Prof. Dominika Wcisło-Dziadecka MD, Department of Cosmetology, School of Pharmacy with the Division of Laboratory Medicine, Medical University of Silesia, 3 Kasztanowa St, 41-200 Sosnowiec, Poland, phone/fax: + 4832 256 11 82 , +48 3225915 80, e-mail: ddziadecka@interia.pl

Received: 11.05.2019, accepted: 31.05.2019. 
nal pathway activated by this cytokine. The effectiveness of treatment measured with the PASI-75 index is over $60 \%$ with therapy lasting more than 60 weeks. In turn, etanercept is a fusion protein consisting of soluble TNF- $\alpha$ receptor linked to the Fc region of IgG1. This drug has the ability to bind to the circulating soluble form of the cytokine. It is administered on a continuous basis and the effectiveness of treatment is assessed after 12 weeks of pharmacotherapy [11-13].

Anti-TNF therapy is one of the most effective methods of treating proinflammatory diseases, however it is associated with numerous adverse effects and loss of drug susceptibility $[11,12]$. Therefore, personalization of therapeutic strategies is an extremely important aspect of diagnosis and treatment. The techniques used in molecular biology helping to develop modern methods of treatment are becoming an increasingly common tool in clinical diagnostics. Learning about changes at the molecular level is also important due to the fact that they precede alterations at the phenotypic level, which creates the possibility of early detection of drug resistance, allowing to improve the therapeutic strategy [14-16].

\section{Aim}

The aim of this study was to determine the possibility of using changes in the expression profile of TNF- $\alpha$ and its receptors TNFR1 and TNFR2 as complementary molecular markers of the efficacy of anti-TNF therapy (adalimumab, etanercept) in patients with psoriasis during the 4-year follow-up. The occurrence or lack of association between molecular parameters and indices of disease severity (PASI, DAS28, BSA) was also examined.

\section{Material and methods}

The study material consisted of the whole blood collected every 12 weeks (one monitoring) from 3 patients with diagnosed psoriatic arthritis initially treated with adalimumab followed by etanercept (patients A, B, C). The deviation from this rule was the result of patient's absence during study material collecting. The clinical and molecular characteristics of these patients were taken into account. For selected samples, the TNF- $\alpha$ expression was determined at the protein level. The control group consisted of 20 healthy volunteers ( 9 women, 11 men), in which changes in the expression profile of the studied cytokines were determined at the mRNA level. The mean age in the study group was $41 \pm 10$ years and $46 \pm 10$ years in the control group. All patients provided informed consent to participate in the study.

The first step of molecular analysis was the isolation of total RNA from whole blood using the FENOZOL reagent (A\&A Biotechnology, Gdańsk, Poland) in accordance with the protocol. Then, a quantitative reverse transcription PCR (RT-qPCR) was performed for mRNA of TNF- $\alpha$, TNFR1, TNFR2 with $\beta$-actin (ACTB) as an endogenous control. The RT-qPCR was carried out with the use of the QuantiTect SYBR Green RT-PCR Kit (Qiagen, Valencia, CA, USA) as recommended by the manufacturer. Detection of serum TNF concentration was performed with MALDI-TOF Mass Spectrometry using the AXIMA Performance MALDI-TOF 2 spectrometer (Shimadzu, Kyoto, Japan) according to the protocol. Clinical analysis was carried out every 12 weeks based on PASI, BSA, and DAS28 parameters.

\section{Ethical approval}

Consent of the Bioethics Commission of the Medical University of Silesia in Katowice/Poland no. KNW/0022/ KB1/59/I/13/14.

\section{Statistical analysis}

Statistica 12.0 PL (StatSoft, Tulsa, Oklahoma, USA) was used to perform statistical analysis $(p<0.05)$. Spearman's rank correlation coefficient was determined between the TNF- $\alpha$ expression profile and clinical parameters (PASI, BSA, DAS28) and among them for each patient.

\section{Results}

The expression profile of TNF- $\alpha$, TNFR1 and TNFR2 (the number of mRNA copies per $\mu$ g of total RNA), concentration of TNF- $\alpha$ protein and parameters of disease severity (PASI, DAS28, BSA) during the 4-year follow-up for each patient are presented in Table 1.

In the control group, the mean value of expression of the analysed genes was as follows: TNF- $\alpha$ : 1149048 \pm 1554419 ; TNFR1: $547826 \pm 777004$; and TNFR2: 1037 \pm 1731 .

When monitoring response to adalimumab therapy in patient A, no TNF- expression was observed (0 copies/ug of RNA), which changed when the drug was switched to etanercept. The highest transcriptional activity of TNF- $\alpha$ is observed until the sixth monitoring and gradually decreases reaching a relatively low level of expression from the twelfth monitoring. By analysing the expression of TNFR1 and TNFR2, it can be noted that during treatment with adalimumab, TNFR2 is more expressed than TNFR1 (TNFR1 < TNFR2), which changes during etanercept therapy (TNFR1 > TNFR2) as reported in the control group. The level of TNF protein in selected samples was relatively constant. The decrease in the values of all clinical parameters describing the severity of the disease was also reported.

At the end of adalimumab therapy, an increased TNF- $\alpha$ expression and PASI, BSA values were observed in patient $B$ before the drug was changed to etanercept. In addition, the expression profile of TNFR1 and TNFR2 during treatment with each anti-TNF drug shows similar- 
Table 1. Molecular and clinical characteristics of patients A, B, and C treated with adalimumab and etanercept

\begin{tabular}{|c|c|c|c|c|c|c|c|c|}
\hline \multirow[t]{2}{*}{ Anti-TNF drug } & \multirow[t]{2}{*}{ Monitoring } & \multicolumn{3}{|c|}{ mRNA [copies/ug RNA] } & \multirow{2}{*}{$\begin{array}{c}\text { Protein } \\
\text { [pg/ml] } \\
\text { TNF }\end{array}$} & \multicolumn{3}{|c|}{ Clinical parameters } \\
\hline & & TNF- $\alpha$ & TNFR1 & TNFR2 & & PASI & BSA & DAS28 \\
\hline \multicolumn{9}{|l|}{ Patient A: } \\
\hline Adalimumab & 1 & 0 & 14 & 329 & & 12.9 & 36 & 3.02 \\
\hline \multirow[t]{15}{*}{ Etanercept } & 0 & 11182692 & 30567 & 16 & 241 & 18 & 34 & 3.98 \\
\hline & 1 & 9684314 & 3785 & 1138 & 262 & 15 & 28 & 1.26 \\
\hline & 2 & 411848 & 26348 & 14 & 193 & 19 & 21 & 3.23 \\
\hline & 3 & 1202857 & 47807 & 14 & 201 & 16 & 19 & 1.61 \\
\hline & 4 & 4767045 & 3619 & 238 & 309 & 17 & 19 & 1.47 \\
\hline & 5 & 3516327 & 10367 & 252 & 226 & 5 & 10 & 2.09 \\
\hline & 6 & 16558333 & 35517 & 88 & & 5 & 10 & 2.72 \\
\hline & 7 & 22850 & 16558 & 136 & & 4 & 4 & 1.61 \\
\hline & 8 & 65517 & 16358 & 377 & & 7 & 10 & 1.61 \\
\hline & 9 & 24850 & 12502 & 92 & & 5 & 12 & 2.09 \\
\hline & 10 & 55733 & 11317 & 199 & & 5 & 9 & 1.12 \\
\hline & 11 & 64050 & 57000 & 170 & & 4 & 7 & 1.61 \\
\hline & 12 & 134 & 198500000 & 11683 & & 4 & 7 & 2.09 \\
\hline & 13 & 119 & 0 & 223 & & 4 & 7 & 1.12 \\
\hline & 14 & 0 & 137 & 3338 & & 4 & 7 & 1.12 \\
\hline \multicolumn{9}{|l|}{ Patient B: } \\
\hline \multirow[t]{2}{*}{ Adalimumab } & 1 & 0 & 14 & 329 & & 5.7 & 30 & 4.27 \\
\hline & 2 & 1598 & 53300 & 58950 & 17 & 14 & 31 & 3.77 \\
\hline \multirow[t]{12}{*}{ Etanercept } & 0 & 5588506 & 1506 & 134 & 114 & 17 & 27 & 4.26 \\
\hline & 1 & 2466949 & 1900 & 11 & 333 & 15 & 26 & 4.26 \\
\hline & 2 & 37333 & 12165 & 232 & 0 & 16 & 20 & 4.34 \\
\hline & 3 & 102217 & 25333 & 224 & 253 & 11 & 17 & 4.22 \\
\hline & 4 & 83867 & 45167 & 143 & & 2 & 10 & 3.95 \\
\hline & 5 & 52183 & 25983 & 215 & & 3 & 10 & 3.61 \\
\hline & 6 & 102217 & 25333 & 224 & & 4 & 7 & 3.31 \\
\hline & 7 & 63550 & 159533 & 1557 & & 4 & 9 & 4.49 \\
\hline & 8 & 83867 & 45167 & 143 & & 4 & 9 & 3.01 \\
\hline & 9 & 0 & 0 & 14 & & 4 & 9 & 3.08 \\
\hline & 10 & 0 & 0 & 83 & & 4 & 10 & 3.42 \\
\hline & 11 & 0 & 0 & 16988 & & 4 & 10 & 3.37 \\
\hline \multicolumn{9}{|l|}{ Patient C: } \\
\hline \multirow[t]{6}{*}{ Adalimumab } & 1 & 0 & 0 & 0 & & 10 & 20 & 4.18 \\
\hline & 2 & 43 & 8450 & 4087 & 0 & 8.5 & 9 & 3.85 \\
\hline & 3 & 7117 & 1934 & 780667 & 0 & 7.2 & 13 & 3.83 \\
\hline & 4 & 97500 & 125889 & 2331 & & 8.8 & 14 & 4.33 \\
\hline & 5 & 37524 & 211647 & 207 & & 3.8 & 8 & 4.08 \\
\hline & 6 & 0 & 0 & 189121 & & 9.6 & 15 & 4.48 \\
\hline \multirow[t]{4}{*}{ Etanercept } & 1 & 10463 & 5372 & 763 & & 9 & 14 & 3.77 \\
\hline & 2 & 9173 & 12198 & 59 & & 10 & 15 & 3.99 \\
\hline & 3 & 411167 & 403333 & 2163 & & 9 & 14 & 3.46 \\
\hline & 4 & 170167 & 188000 & 1623 & & 5 & 13 & 3.63 \\
\hline
\end{tabular}


ity to that noted in patient A, although for the last three monitorings of etanercept therapy, an increase in transcriptional activity of TNFR2 can be observed compared to TNFR1, as in adalimumab treatment. In the initial stages of monitoring the effectiveness of etanercept, it can be noted that TNF- $\alpha$ expression is silenced from the ninth monitoring. Analysis at the proteome level showed a relatively high increase in TNF expression in the first monitoring period after treatment change and the tendency to silence it after drug administration. Based on clinical parameters of monitoring the effectiveness of therapy, their higher values can be observed in treatment with adalimumab. During the etanercept therapy, a gradual reduction in disease severity is reported based on the indicators of clinical response to treatment.

In patient $\mathrm{C}$, the evaluation of the efficacy of adalimumab therapy consisted of six monitorings, during which no TNF expression at the protein level was reported, while the observation of etanercept therapy included four monitorings. The ratio of TNFR1 to TNFR2 was the same as previously reported. With regard to TNF- $\alpha$, the heterogeneity of its expression is observed. During the monitoring of the effectiveness of adalimumab, there is a jump in the values of clinical parameters, which remain at a relatively constant level up to the fourth monitoring of etanercept therapy. Comparison of the transcriptional activity of the examined genes between the study and control groups shows a lower expression of TNF- $\alpha$ among patients on anti-cytokine therapy. Analysis of the TNFR1 $>$ TNFR2 expression ratio indicates a similar trend in the number of transcripts of these genes among healthy volunteers and patients during etanercept therapy and the reverse one during adalimumab treatment.

The next part of the study was to examine the possible occurrence of statistically significant $(p<0.05)$ Spearman's correlation between the expression of the analysed genes and parameters of disease severity (PASI, BSA, DAS28) for each patient and the relationship between clinical indicators. We observed correlations between mentioned parameters only during etanercept therapy (patients $\mathrm{A}$ and $\mathrm{B}$ ) and for patient $\mathrm{C}$ during treatment with adalimumab and etanercept. The correlation between TNF- $\alpha$ and TNFR1 expression was reported for patient B ( $r s=0.534719)$ and patient C ( $r s=0.851852$ for adalimumab; $r s=0.88571$ for etanercept), while for patient $C$ the correlation between TNF- $\alpha$ and TNFR2 expression was found during etanercept therapy ( $r s=$ 0.82857). Our results showed a correlation between gene expression and clinical parameters as follows: TNF- $\alpha$ and PASI (patient A, $r S=0.728716$ ), TNF- $\alpha$ and BSA (patient A, $r s=0.758441$ ), TNFR1 and DAS28 (patient A, rs = 0.654799; patient $C, r s=-0.811679$ for adalimumab). We also observed a correlation between PASI and BSA in patient A ( $r s=0.935905)$, patient $B(r s=0.642966)$, patient $C$ on adalimumab ( $r s=0.42857)$ and between BSA and DAS28 in patient $B(r s=0.606988)$.

\section{Discussion}

The studies performed as part of this work were conducted for patients with psoriatic arthritis admitted to the anti-TNF drug programme. These patients were initially qualified for treatment with adalimumab based on the interview, examination and parameters of disease severity. However, according to accepted standards, a phenotypic loss of susceptibility to adalimumab based on the PASI, BSA, and DAS28 was observed after some time of pharmacotherapy $[17,18]$. Therefore, the decision was made to change the anti-TNF drug to etanercept. In our study, we focused on determining the possibility of links between molecular indicators of inflammation (TNF- $\alpha$, TNFR1, TNFR2) and indicators of clinical response to treatment. Furthermore, we have established the possibility of earlier detection of emerging drug resistance based on the expression of the analysed molecular markers. This course of action seems justified due to the increasingly complex individual approach to the patient [19] and the fact that molecular alterations precede phenotypic changes [14-16]. The effectiveness of anti-TNF therapy is evidenced by the fact that we observed a lower TNF- $\alpha$ expression in the study group than in the control group. Research conducted by Shveta et al. confirms the involvement of TNF- $\alpha$ in the pathogenesis of psoriasis and in combination with our observations demonstrate the validity of anti-TNF therapy [20]. Nevertheless, our study indicates the insufficient efficacy of adalimumab treatment, which results in a change of the drug to etanercept, without negating the importance of using these drugs in anti-TNF therapy. Patients received the same doses of adalimumab and etanercept according to the guidelines. The control of clinical and molecular parameters was performed every 12 weeks. In our previous work on the dermal fibroblast model we showed that changes in the gene expression pattern under the influence of the anti-TNF drug are already observed after 2-hour exposure of the cells to the drug [21]. It is extremely important to find a universal molecular marker of response to the drug and the development of the inflammatory process [22, 23]. In addition to the determination of the clinical parameters and changes in TNF- $\alpha$, TNFR1, and TNFR2 expression at the mRNA level for all periods of monitoring the efficacy of antiTNF therapy, the level of TNF- $\alpha$ protein was evaluated in selected samples. Analysis of the transcriptional activity of TNF- $\alpha$ receptors showed that TNFR1 expression is lower than TNFR2 during treatment with adalimumab, while for etanercept therapy and in the control group it is reversed. It is believed that changes in the expression of TNF- $\alpha$ receptors may be indicators of the severity of inflammatory changes in the joints [24]. Gola et al. also reported a higher TNFR2 expression compared to TNFR1 when exposing RPTEC cells to AmB-Cu+ ${ }^{2+}$ noting that the observed changes may result from the less toxic effect of 
AmB-Cu+ ${ }^{2+}[25]$, also indicating the induction of repair processes by this form of the drug [26]. However, regarding the changes observed in our study, it can be concluded that anti-TNF therapy affects the genes associated with the TNF signal pathway by altering the expression of receptors for this cytokine. Moreover, the profile of changes in receptors expression depends on the type of anti-TNF drug and the observed TNFR1/TNFR2 ratio may result from a different structure and mechanism of action of adalimumab and etanercept [4, 9, 10, 27]. However, given the fact that we noted a higher transcriptional activity of TNFR1 than TNFR2 in the control group, etanercept does not appear to be toxic.

During the whole period of etanercept treatment, the level of TNF- $\alpha$ expression was higher than during adalimumab therapy. However, the observation of the therapeutic potential of adalimumab has been carried out for a relatively short time. On the one hand, changes in the transcriptional activity of TNF- $\alpha$ during treatment with adalimumab may be related to its mechanism of action, but on the other hand they may be a molecular manifestation of drug resistance. The increase in TNF- $\alpha$ expression observed in the first monitorings after the inclusion of etanercept may result from the extension of the inflammatory process to peripheral joints. TNF- $\alpha$ stimulates the secretion of extracellular matrix metalloproteinases (MMPs), responsible for the remodelling of extracellular matrix of the articular cartilage, from infiltrating inflammatory cells [27]. In addition, previous reports confirming an elevated concentration of TNF- $\alpha$ during etanercept therapy associated with its long halflife in serum should be taken into account [28]. Moreover, it is suggested that the level of TNF- $\alpha$ and its receptors can be used as an indicator for selecting the appropriate dose of etanercept and the effectiveness of therapy $[29,30]$. It would also explain a relatively constant concentration of TNF protein in our study group. We evaluated TNF- $\alpha$ expression at the proteome level during the first few monitoring periods to assess the relationship of its expression at the mRNA and protein levels, however, based on the obtained data, it is difficult to determine this association.

TNFR1 is present on the majority of nucleated cells and mediates the cascade of reactions leading to apoptosis, whereas TNFR2 is present only on certain cells and participates in $T$ cell proliferation [31, 32]. The changes observed with respect to these receptors may indicate that various biological processes dominate depending on the anti-TNF drug (adalimumab, etanercept). It would suggest that adalimumab mainly stimulates signalling cascades associated with the induction of T cell proliferation, while etanercept leads to programmed cell death $[31,32]$. Our study showing the increased expression of TNFR2 compared to TNFR1 during etanercept therapy seems to confirm its efficacy. The key factor hindering the effective treatment of psoriasis is the fact that psori- atic keratinocytes are resistant to apoptosis and that this process affects the immune system disorders observed in psoriasis $[33,34]$. For this reason, the increased participation of TNFR1 and the pro-apoptotic pathways may become a crucial element in the effectiveness of treatment, indicating a positive therapeutic effect. It should be noted that changes in the expression of TNF- $\alpha$ and its receptors may result from the emergence of drug resistance and possibly also from the interaction of interferon $\gamma$ (IFNG) [35], which increases TNF- $\alpha$ secretion and induces its receptors expression $[36,37]$. It may explain the increase in the transcriptional activity of this gene when the anti-TNF therapeutic strategy is changed. During molecular observation of patients, relatively large fluctuations in the expression of the analysed genes between consecutive administration times of the next dose can be noted. It may result from individual variability manifested by a different rate of drug metabolism [38, 39]. It was observed that people suffering from plaque psoriasis are characterized by a faster rate of drug metabolism dependent on the CYP2D6 genotype [40]. As part of this work, we determined the relationship between disease severity indices (PASI, DAS28, BSA) and molecular parameters of the severity of inflammation. We noted a positive correlation between TNF- $\alpha$ and PASI, TNF- $\alpha$ and BSA, which are indicators informing about the body surface area covered by psoriatic lesions. We also found a correlation between TNFR1 and DAS28, a parameter for assessing the inflammation severity in the joints. It is worth noting that etanercept is dedicated to patients with psoriatic arthritis, and the observed profile of TNFR1 expression during therapy with this drug seems to indicate its therapeutic potential and the possibility of using TNFR1 as a marker of the severity of joint changes, whereas TNF- $\alpha$ better defines the severity of skin lesions. It can be concluded that with the rise in the number of copies of the TNF- $\alpha$ or TNFR1 transcripts, the PASI, BSA, and DAS28 parameters increase and thus effective anti-TNF therapy should aim to reduce the expression of cytokines. Serefican et al. also indicated a higher level of TNF- $\alpha$ expression in the group of patients with psoriasis compared to the control group and found a statistically significant positive correlation between the expression of TNF- $\alpha$ and PASI [41]. Shveta et al. [20] observed a decrease in the PASI index and TNF- $\alpha$ concentration after treatment of patients with psoriasis. However, on the basis of our study, the decrease or increase in the expression of the analysed genes does not correlate with the multiplicity of changes in clinical parameters, therefore the determination of TNF- $\alpha, T N F R 1$ and TNFR2 expression should be considered as a valuable complementary study, indicating a tendency of the patient's response to treatment. We observed a higher level of TNF- $\alpha$ protein than described by Korczowska-Łącka et al. in patients with ankylosing spondylitis [42], which may be due to the modulation of the cytokine expression by the drug and simultaneous 
occurrence of joint and skin symptoms of psoriasis in our study group.

A full analysis of the changes in expression at the transcriptome and proteome levels along with the clinical parameters and individual approach to the patient creates the possibility to increase the effectiveness and safety of pharmacotherapy.

\section{Conclusions}

The efficacy, safety and success of the therapy depend on the selection of appropriate markers to monitor the response to the drug. TNF- $\alpha$, TNFR1, and TNFR2 seem to be good complementary markers of the advancement of inflammatory processes including plaque psoriasis and psoriatic arthritis. They also allow to determine the effectiveness of treatment and increase the precision of earlier detection of emerging drug resistance in anti-TNF therapy.

\section{Acknowledgments}

This research was financed by the Medical University of Silesia in Katowice/Poland on the basis of decision no. KNW-1-029/N/6/0. This research was supported in part by PLGrid Infrastructure.

\section{Conflict of interest}

The authors declare no conflict of interest.

\section{References}

1. Tsoi LC, Stuart PE, Tian C, et al. Large scale meta-analysis characterizes genetic architecture for common psoriasis associated variants. Nat Commun 2017; 24: 1-8.

2. Szepietowski J, Adamski Z, Chodorowska G, et al. Leczenie łuszczycy - rekomendacje ekspertów Polskiego Towarzystwa Dermatologicznego. Część druga: tuszczyca umiarkowana do ciężkiej. Przegl Dermatol 2014, 101: 455-72.

3. Baran A, Kiluk P, Myśliwiec H, Flisiak I. Znaczenie lipidów w łuszczycy. Przegl Deramtol 2017; 104: 619-35.

4. Michalak-Stoma A, Bartosińska J, Kowal M, et al. Serum levels of selected Th17 and Th22 cytokines in psoriatic patients. Dis Markers 2013; 35: 625-31.

5. Szepietowski J, Adamski Z, Chodorowska G, et al. Rekomendacje Polskiego Towarzystwa Dermatologicznego dotyczące stosowania leków biologicznych w łuszczycy zwyczajnej i stawowej (łuszczycowym zapaleniu stawów). Przegl Dermatol 2010; 97: 1-13.

6. Wcisło-Dziadecka D, Zbiciak M, Wcisło-Brzezińska L, Mazurek U. Anti-cytokine therapy for psoriasis - not only TNF blockers. Overview of reports on the effectiveness of therapy with IL12/IL23 and T and B lymphocyte inhibitors. Post Hig Med Dosw 2016; 70: 1198-205.

7. Wcisło-Dziadecka, Zbiciak-Nylec M, Brzezińska-Wcisło L, et al. Newer treatments of psoriasis regarding IL-23 inhibitors, phospodiesterase 4 inhibitors, and Janus kinase inhibitors. Derm Ter 2017; 30: 1-8.
8. Jaśkiewicz-Nyckowska D, Szczerkowska-Dobosz A, Czubek M, Purzyńska-Bohdan D. Problemy dotyczące fałszywie dodatnich testów laboratoryjnych podczas kwalifikacji do programu „Leczenia ciężkiej postaci łuszczycy plackowatej” na podstawie dwóch przypadków. Przegl Dermatol 2015; 102: 33-6.

9. Kwiek B, Narbutt J, Sysa-Jędrzejowksa A, et al. Long-term treatment of chronic plaque psoriasis with biological drugs can control platelet activation: targeting the bridge between inflammation and atherothrombosis. Adv Dermatol Allergol 2017; 34: 131-7.

10. Sebastan A, Wojtala P, Lubiński Ł, et al. Disease activity in axial spondyloarthritis after discontinuation of TNF inhibitors therapy. Reumatologia 2017; 55: 155-62.

11. Roda G, Jharap B, Neeraj N, Colombel JF. Loss of response to anti-TNFs: definition, epidemiology, and management. Clin Transl Gastroenterol 2016; 7: e135.

12. Pełka M, Broniarczyk-Dyła G. Zastosowanie leków biologicznych w dermatologii. Adv Dermatol Allergol 2007; 24: 35-41.

13. Kucharz EJ. Mechanizmy immunologiczne w patogenezie reumatoidalnego zapalenia stawów. In: Enbrel. Zastosowanie kliniczne. Szechiński J (ed.). Wydawnictwo Medyczne Górnicki, Wrocław 2008; 1-9.

14. Opławski M, Michalski M, Witek A. Identification of a gene expression profile associated with the regulation of angiogenesis in endometrial cancer. Mol Med Rep 2017; 16: 2547-55.

15. Biankin VA, Piantadosi S, Hollingsworth SJ. Patient-centric trials for therapeutic development in precision oncology. Nature 2015; 526: 361-70.

16. Le Tourneau C, Kamal M, Tsimberidou AM, et al. Treatment algorithms based on tumor molecular profiling: the essence of precision medicine trials. J Natl Cancer Inst 2015; 108: djv362.

17. Bożek A, Reich A. How to reliably evaluate the severity of psoriasis? Forum Dermatol 2016; 2: 6-11.

18. Spuls PI, Lecluse LL, Poulsen ML, et al. How good are clinical severity and outcome measures for psoriasis? Quantitative evaluation in a systematic review. J Invest Dermatol 2010; 130: 933-43.

19. Bosman FT, Yan P. Patologia molekularna raka jelita grubego. Pol J Pathol 2014; 65: S1-11.

20.Shveta, Agarwal K, Chander R, Agarwal S. Serum levels of se-selectin, TNF-alpha and IL-1beta in patients of psoriasis before and after topical therapy in patients of psoriasis. IJCR 2017; 9: 55837-40.

21. Wcisło-Dziadecka D, Grabarek B, Zmarzły N, et al. Influence of adalimumab on the expression profile of genes associated with histaminergic system in the skin fibroblasts in vitro. BioMed Resh Int 2018; 2018: 1582173.

22. Michalska-Bańkowska A, Wcisło-Dziadecka D, Grabarek B, et al. Variances in the mRNA expression profile of TGF 1-3 isoforms and its TGF $\beta$ RI-III receptors during treatment of psoriatic patients with cyclosporin A. Adv Dermatol Allergol 2018; 35: 502-9.

23. Grabarek B, Bednarczyk M, Mazurek U. The characterization of tumor necrosis factor alpha (TNF-alpha), its role in cancerogenesis and cardiovascular system diseases and possibilities of using this cytokine as a molecular marker. Acta Univ Lodz Folia Biol Oecol 2017; 13: 1-8.

24. Heilig B, Wermann M, Gallati H, et al. Evaluation TNF receptor plasma concentrations in patients with rheumatoid arthritis. Clin Investig 1992; 70: 22-7. 
25. Gola J, Strzałka-Mrozik B, Kruszniewska-Rajs C. A new form of amphotericin B - the complex with copper (II) ionsdownregulates STNFR1 shedding and changes the activity of genes involved in TNF-induced pathways: AmB-Cu2+ downregulates STNFR1 shedding and changes the activity of genes involved in TNF-induced pathways. Pharmacol Rep 2017; 69: 22-8.

26. Gola J, Strzałka-Mrozik B, Wieczorek E. Amphotericin B-copper (II) complex alters transcriptional activity of genes encoding transforming growth factor-beta family members and related proteins in renal cells. Pharmacol Rep 2017; 69: 1308-14.

27. Szeremeta A, Olczyk K. Tumor necrosis factor alpha antagonists in the treatment of the patients with rheumatoid arthritis. Reumatologia 2012; 50: 438-43.

28. Madhusedan S, Foster M, Muthuramalingam SR, et al. A phase II study of etanercept (Enbrel), a tumor necrosis factor a inhibitor in patients with metastatic brest cancer. Clin Cancer Res 2004; 10: 6528-34.

29. Sato M, Takemura M, Shinohe R, Shimizu K. Serum cytokine concentrations in a patient with rheumatoid arthritis on etanercept therapy who subsequently developed pneumocystis pneumonia: a case report. Case Rep Rheumatol 2011; 2011: 1-4.

30.Schulz M, Dotzlaw H, Neeck G. Ankylosing spondylitis and rheumatoid arthritis: serum levels of TNF-alpha and its soluble receptors during the course of therapy with etanercept and infliximab. BioMed Res Int 2014; 2014: 975108.

31. Webb KC, Tung R, Winterfield LS, et al. Tumour necrosis factor-alpha inhibition can stabilize disease in progressive vitiligo. Br J Dermatol 2015; 173: 641-50.

32. Lisa M, SedgerMichael F, McDermott. TNF and TNF-receptors: from mediators of cell death and inflammation to therapeutic giants - past, present and future. Cytokine Growth FR 2014; 25: 453-72.

33. Myśliwiec H, Baran A, Flisiak I. Wybrane aspekty apoptozy w łuszczycy. Przegl Dermatol 2017; 104: 57-63.

34. Vomero M, Capozzi A, Barbati C, et al. FRI0028 In vitro inhibitory effect of etanercept on autophagy: a new mechanism of action of TNF inhibitors in rheumatoid arthritis. Ann Rheum Dis 2017; 76: 490.

35. Iborra M, Beltrán B, Bastida G, et al. Infliximab and adalimumab-induced psoriasis in Crohn's disease: a paradoxical side effect. J Crohns Colitis 2011; 5: 157-61.

36. Bosè F, Raeli L, Garutti C, et al. Dual role of anti-TNF therapy: enhancement of TCR-mediated T cell activation in peripheral blood and inhibition of inflammation in target tissues. Clin Immunol 2011; 139: 164-76.

37. Wang F, Schwarz BT, Graham WV, et al. IFN-gamma-induced TNFR2 expression is required for TNF-dependent intestinal epithelial barrier dysfunction. Gastroenterol 2006; 131: 1153-13.

38. Rychlik-Sych M, Barańska M, Skrętowicz J. Clinical significance of pharmacogenetics in dermatological diseases. Przegl Lek 2012; 69: 120-4.

39. Niemira M, Wiśniewska A, Mazerska Z. Polymorphism and the level of P450 gene expression in xenobiotic metabolism. Post Bioch 2009; 55: 279-89.

40.Czarnecka A, Niewiński P, Orzechowska-Juzwenko K, et al. Genotyp oksydacji CYP2D6 jako czynnik zwiększający ryzyko wystapienia łuszczycy zwykłej. Derm Klin 2005; 7: 25-7.

41. Serefican H, Goksugur N, Bugdayci G, et al. Serum visfatin, adiponectin, and tumor necrosis factor alpha (TNF-alpha) levels in patients with psoriasis and their correlation with disease severity. Acta Dermatolvenerol Croatia 2016; 24: 13-9.

42. Korczowska-Łacka I, Przepiera-Bedzak H, Brzosko M, et al. Stężenie TNF, receptorów TNF RI i RII oraz wybranych markerów ostrej fazy u chorych na zesztywniające zapalenie stawów kręgosłupa. Reumatologia 2009; 47: 10-4. 